\title{
Translating paratextual elements of online news texts from English into Ukrainian
}

\author{
Ruslana Dovhanchyna*1 \\ ${ }^{1}$ Taras Shevchenko National University of Kyiv, the Institute of Philology, the Department of Theory \\ and Practice of Translation from English, 14 Taras Shevchenko Blvd, Kyiv, 01601, Ukraine
}

\begin{abstract}
The paratext is defined as textual and visual elements that surround and support the core text. It is also any material additional to, appended to or external to the content, which has functions of explaining, defining, instructing, supporting, or adding background information, the relevant opinions and attitudes of scholars, translators and reviewers. The article examines the significance of the paratext and its components in the translation of online news texts. The objective of the paper is to demarcate a theoretical framework based on literary criticism, media and translation studies, which can provide the ground for media translators and researchers. In particular, this paper determines the paratext and paratextual elements within the scope of news discourse; singles out the most potent paratextual elements in news translation; and presents the most frequent challenges of rendering paratextual elements in the translation of online news texts from English into Ukrainian. The research provides some insights brought by the notion of the paratext to translation studies, as well as the neighbouring disciplines of digital and media studies. The analysis highlights the complex paratextual elements, which have never ceased to challenge translators, mainly headlines, subheadings and leads of online news texts.
\end{abstract}

\section{Introduction}

Lately the study of media translation has grown significantly $[1,2,3]$ and linguistic, cultural, and ideological aspects of news texts have gained the most interest of researchers $[4,5,6]$. The close attention to paratextual elements in news discourse and especially in digital media and thus new forms of text production and consumption has led to fresh insights into news text specificity [6]. Nowadays media scholars emphasise that "paratextual units of news texts constitute a coherent and relatively autonomous microsystem, despite certain structural and functional differences, and that this microsystem is placed as a text strategic field (threshold) between the sender and receiver of news text" [6]. The paratext is textual and visual elements that surround and support the core text. It is also any material additional to, appended to or external to the core text which has functions of explaining, defining, instructing, supporting, or adding background

Corresponding author: dovganchina1@gmail.com 
information, the relevant opinions and attitudes of scholars, translators and reviewers. The issues of the paratext have been studied more profoundly in literary studies $[7,8]$, when translation aspects of paratextuality in mass media are still beyond proper consideration.

The term "paratext" was coined by the French literary critic Gérard Genette. The first elaborate research on the paratext was carried out in his book Seuils [7] translated into English as Paratexts: Thresholds of Interpretation [8]. The main text of a writer is often surrounded by other materials supplied by authors, editors, and publishers, which are known as the paratext. A "threshold", or "seuil" in French, is a very good explicative metaphor for the notion of the paratext: "para" meaning beyond or adjacent to; and the root "text" referring to the written word. At first, the paratext was mostly associated with books, as they typically include a cover, title, front matters such as dedication, opening information, foreword and back matters such as endpapers, colophon [9]. Moreover, books often contain footnotes and many other materials not crafted by the author. Consequently, the theory of paratextuality has sparked interest of different literary representatives: editors, publishers, promoters and so on. The paratext has caught the immediate attention of translation scholars, who are always eager to investigate the elements that connect translated texts with their readers, and therefore significantly influence their reception. Since the very beginning of the 21 century the term "paratranslation" $[10 ; 11 ; 12 ; 13]$ has been used regarding the basic approaches to conveying paratextual elements. J.Frias and G.Lathey reveal the role of the paratext and translators in children's literature $[10 ; 14]$. The paratext has been defined as common elements provided within a book - peritext; and elements outside of the book - epitext [8]. Peritextual elements can include the foreword, table of contents, index, and source notes. Epitextual features refer to communication outside the book that can influence whether and how the text is read. Book reviews, interviews, author websites and letters, and critical literary analyses are examples of epitextual components. Some aspects of paratranslation in the theatre are raised in J.Braga Riera's article, which deals with the potential influence of epitexts (reviews, webpages, videos, posters, flyers and programmes) on the reception of a particular stage play in a different culture, as well as with the significance of the translator in the process of theatrical adaptations [12]. The verbal and non-verbal elements of the paratext have been studied by V.Pellet in Chinese-English translation [11]. R.Skare examines the paratext in various digital studies [9]; M.Carter [15], D.L.Burk [16], A.Rockenberger [17] - in computer games; G.Stanitzek [2], J.Gray [18], M.Gross and D.Latham - in education, S.Perse and P.Noto [3] - in film and television.

In the book Translation and Paratexts, Kathryn Batchelor [13] analyses thoroughly the academic works of G.Genette, who has had a broad impact on the development of transtextuality in general and the paratext in particular. Metaphorically, G.Genette calls paratextual elements "the thresholds of interpretation" or sometimes a "vestibule" or "undefined zone" between the inside and the outside, which offers the world at large the possibility of either stepping inside a book or turning back [8]. The famous proverb "the book is judged by its cover" has more literal meaning than a figurative one in G.Genette's perspective. The so-called added elements to a book form a frame for the main text, and can change its reception or interpretation by the public. He includes into the paratext the following components: the author's name, title, subtitle, the editor's name, prefaces and all possible fringe elements of a book. K.Batchelor believes that these elements, if they are appealing enough for the reader, encourage consumers to step from the outside into the inside world of a book [13]. She investigates the relevance of the paratext for translation studies and creates a framework for further research, addressing questions of terminology, typologies, methodology and research topics.

So the paratext is a term initially used in literary interpretation, but G.Genette's concept has proven to be productive in other fields than literary studies. While paratextual elements 
in literary works may be subordinate to the text, media scholars $[5,6]$ state that they are the most important components in news discourse, as paratextual elements are the first encounter for a potential reader or viewer. Paratextual elements are of paramount importance in writing as well as in the perception of news texts, and journalists see them as top priority. They are sometimes referred to as "the fringe of the printed text" [8] which, actually, controls the whole reading. The primary task of a media translator is to get "the fringe benefits" of paratextual elements, so that these constituents could become competitive and rewarding in the target news text. The reader's assumptions about the content of a news text, its quality and trustworthiness depend on the translator's interpretation of paratextual elements and their further design. R.Skare indicates that most of the paratextual elements explored by G.Genette are textual parameters, but there are also non-textual manifestations: iconic such as illustrations; material, for instance, typography, format, paper quality; and factual - the author's name, reputation, awards and so on [9].

While studying the paratextual elements of news texts in the perspective of the interdisciplinary approach, which combines the theories of literary criticism, media and translation studies, we can conclude that paratextual elements thus are liminal textual and visual constituents related to the main text in a way that enables the work to be complete and offered to its readers and, more generally, to the public. Having analysed news in the press as a specific type of discourse, T.A. van Dijk pointed out the main features of news discourse: "...more than in any other type of text, macrostructures are explicitly expressed in the news report, as headlines and leads" [4]. Considering news texts from the translator's perspective, we can conclude that such paratextual elements as headlines and leads, which T.A. van Dijk calls "the summary of news texts", demand the closest attention in translation. These elements are considered to be "the intensive positions" in stylistics too [20]. Paratextual elements can be seen at the beginning and the end of news texts, mainly the headline, the lead, the subheading and some possible "tail" components. But we must remember that sometimes they can be in the middle: some author's or editor's remarks in brackets, pictures, tweets and so on. The current tendency to insert some tweets into the body of the text can be observed in many newspapers.

\section{Materials, main objectives and methods of investigation}

Our observations are based on more than 570 online news texts from 25 English and Ukrainian newspapers and magazines, which have been analysed in the course of Translation of Modern Social and Political Texts designed for undergraduate students studying at the Translation Department of Taras Shevchenko National University in Kyiv. This course has been taught for five years and prepared future translator to professional work in the sphere of media industry.

This analysis intends to present cultural and social implications of paratextual elements, which are really essential to convey in news translation. So, the main objectives of the research are to answer the following questions:

○ Which paratextual elements are top priority in the translation of news texts?

o What challenges are we to deal with while translating the paratextual elements of news texts?

The application of the paratextual analysis into our study alongside with traditional content, comparative and descriptive methods allows broadening the scope of this research. Comparative and descriptive methods are used in order to single out similar and distinct features of news in English and Ukrainian languages. The content investigation is required to substantiate certain translation decisions studied in the article. The paratextual analysis helps to understand that a new notion "paratranslation" has wide implications, as it can be applied not only to pure translation but also to the spheres of editing, publishing and 
design of news texts. Thus the term "paratranslation" presupposes that the frames of translation can be considerably augmented, incorporating all possible paratextual verbal and non-verbal components. Moreover, in media translation it frequently happens that one target news text is created from several source texts. For instance, in Ukraine we can find only the $\mathrm{BBC}$ and Voice of America services which provide news online in English and Ukrainian. Having analysed BBC news features, we conclude that very few articles can be regarded as full translations of source texts. And if some source texts are blended into a target one, usually, the most high-powered paratextual elements are brought into the target culture. Considering all relevant factors, only verbal paratextual elements are to be explored in this article, as their representation and interpretation greatly depend on the decisions and choices of translators and editors. Non-verbal items can be optional in translation and depend mostly on the publishers of certain media sources and their publishing policy. Taking into account that in Ukraine we have nowadays only two news services available in both languages (in English and Ukrainian), the research demonstrates the translation examples taken from BBC Ukrainian service, as well as the samples of students' translations collected in the result of the experiment conducted at the Translation Department of Taras Shevchenko National University in Kyiv. In order to comprehend the role of paratextual elements in translating news, the students participating in the experiment had to take three basic stages:

1. Firstly, the students were asked to translate particular news headlines separately from news texts.

2. Then the students were given the same headlines supplemented by leads and sometimes subheadings. If the students saw it necessary to make some changes or corrections of their previous versions, they took appropriate decisions.

3. Finally, the whole news texts were proposed to the students, and they had a chance to make final corrections.

Eventually, we have made a comparative analysis of the first, middle and final versions of their translations and singled out the similarities and dissimilarities between them.

\section{Paratextual elements of news texts in the framework of translation}

News translators regard paratextual elements as part and parcel of translated texts as they can reach the reader before the translation itself. They are expected to offer reliable but at the same time memorable information. Translating news texts, we should remember how people read and especially now, when we mostly search for information online. Dealing with paratextual elements, it should be kept in mind that they are in many cases adjusted to or even sometimes substituted for new ones coined according to the stylistic rules of the target language and expectations of the target audience. That is why it is impossible to translate for media without comprehending and assimilating the main rules of journalism. Trying to point out the most relevant paratextual elements in translation, we have to take into account the main principle of news structure, which is known as "the inverted pyramid". The "inverted pyramid" structure organizes all facts in the story in order of importance, so that what was lost at the end of the story was the least significant material [21]. T.A. van Dijk states that news, at least globally, displays a "top-down, schema-driven and relevance-dependent" realisation of information, which means that important information comes first [4]. This structure works admirably for most news texts because the consumers who are interested in further information can keep reading, while other readers, who stop early, still get the most important information. The task which is put before media translators is to render the headline in the way which is powerful enough to make the reader go on to the second sentence - usually the lead. Rendering the paratext, it is relevant to take 
some crucial factors into consideration. Firstly, the specificity of news translation is that media translators frequently have to combine translation and journalistic skills as an essential prerequisite for their professional activity. It is especially obvious in the countries whose languages are not as dominant in the modern world as English. Nowadays most media content is being spread in English, while such cultures as the Ukrainian one often rely on English source materials to highlight international news and events. Secondly, today's fast-paced society is transforming reading habits due to current increasing dependence on the Internet. Most readers just skim headlines and some adjacent information sections and if they are not appealing and informative enough, they know that there are plenty of other sources easily accessible at one click. Headlines, leads and subheadings in news texts are to be attention-catching, as they are the first encounters with the reader. They reveal important shades of meaning and create implicit layers of the text as a whole. The experiment conducted at the Translation Department of Taras Shevchenko National University in Kyiv proves that a translation analysis can never be complete without incorporating all essential components surrounding news texts such as headlines, leads and subheadings.

\subsection{Headlines or "MAN BITES DOG"}

The headline "MAN BITES DOG" is a classic journalism aphorism about the difference between an everyday event and news. It was first used for The Washington Post's front page in 1950 and is attributed to Mark Twain's quote: "When a dog bites a man, that is not news, because it happens so often. But if a man bites a dog, that is news" [22]. The phrase describes how an unusual, infrequent title is considered more likely to attract readers. The phenomenon is also described in the journalistic maxim: "You never read about a plane that did not crash" [22]. These mantras are well known among journalists, but it does not mean that translators are always aware of them. What we are to remember in translation: it is necessary to catch the reader's eye with a headline. The mistake many students make is that they translate headlines hastily or leave them out entirely, not realizing their real purpose. Translated headlines should be so appealing to the reader that they convince them to plough straight in and continue reading. To be good at translating headlines, students must learn the art of headlinese. Translating headlines, students should remember that they are, to some extent, the criterion of journalistic skills, talent and culture. And as it has already been mentioned, most readers (according to some data to 80 percent [22]) pay attention only to headlines and leads. Hannah Rock, a chief editor at The Times, is the final checkpoint for newspaper stories and makes sure the headlines stand up, make sense and encourage the reader to dive into the story. She offers some tips for writing a headline for online news, which are really useful to follow in translation: to capture the key message of the story and create a headline that best encapsulates the story and then inject some life into the headline and gear it for online. Discussing stylistic devices, H. Rock insists on using puns appropriately [23]. Puns in headlines can be real challenges in news translation:

OUR CONSPIRACY THEORIST-IN-CHIEF [24].

The term "commander-in-chief" has a Ukrainian equivalent “головнокомандувач", which is also a compound noun. But we cannot create a compound noun in the case of this neologism in translation and have to resort to neutralisation:

ГОЛОВНИЙ КОНСПІРАЦІОНІСТ США.

Although reading the news text, it becomes clear that we can see double deformation of the compound part "chief". CNN discusses President Donald Trump's decision to retweet a baseless conspiracy theory and implies his position as a chief executive in the USA. The pun from the source text is inevitably lost in translation, but the substitution of the pronoun 
"OUR" by the name of the country "США" makes this "short story" transparent to some extent and at the same time intriguing for the target audience.

F.Frandsen examines "the headline system" which can also incorporate the superheadline (found at the top of the newspaper's front page), the main headline and the subheadline, which is a heading preceding the main text, or a group of paragraphs of the main text [6].

\subsection{Subheadings}

The subhead can be either a subordinate title under the main headline, or the heading of a subsection of the article [22]. Extended news texts often have more than one subheadings. It is also common to insert subheadings that help to structure information and make a news text more coherent and consistent. If the first objective of most news texts is to catch the reader's eye with a headline, the task of a subheading is to make them take a step closer to the very gist of the story. So when the headline is a name for a piece of writing, the subheading can be an alternate headline or give further explanation of the title. Both work together to build curiosity and tell the reader what the piece is about. It is a success if this cooperation between the title and subheading is conveyed in translation. Subheadings can divide a news text into some reader-friendly parts, as the example below demonstrates:

\section{Heading: OBITUARY: KARL LAGERFELD, CHANEL'S ICONIC FASHION} DESIGNER

Lead: There is a reason why Karl Lagerfeld, who has died at the age of 85, was called the emperor - or "Kaiser" in his native German - by fashion insiders.

Subheading: A star is born [25].

We can see the same structure in the Ukrainian translation:

Heading: КАРЛ ЛАГЕРФЕЛЬД: КАЙЗЕР СВІТУ МОДИ І ЛЕГЕНДАРНИЙ КЕРІВНИК СНАNEL

Lead: У вівторок, 19 лютого, стало відомо, щзо Карл Лагерфельд помер у 85 років. Представники фешн-індустрії називали його “кайзером”, й на це є причини.

Subheading: Народження зірки [26].

The headline and the lead have undergone some transformations, mainly transpositions ("Kaiser" is moved to the headline and then again repeated in the lead) and additions (the day and the date are supplemented in the lead). The subheading, which is allusive to the Hollywood musical "A Star is Born", is conveyed in Ukrainian by a nominal sentence preserving the translated name of the film "Народження зірки".

Subheads are thus one type of entry point that help readers make choices, such as where to begin or stop reading.

\subsection{Leads}

The lead is the first sentence or paragraph of a news text, which summarises the point of the story and encourages people to keep reading. It is located below the headline and is usually graphically distinct from the body of the text, so media scholars see it as an essential part of paratext. The lead should capture the essence of who, what, when, where, why and how but without giving away the entire context. The translator has to be aware that the main task of the lead is to grab the attention of the reader. If not attention-grabbing, it is sometimes called "burying the lead" [27]. William Zinsser in his book On Writing Well: The Classic Guide to Writing Nonfiction mentions: "The most important sentence in any article is the first one. If it doesn't induce the reader to proceed to the second sentence, your article is dead" [28]. F.Frandsen states that the headline and the lead constitute a coherent and relatively autonomous microsystem [6]. Some illustrative examples have been taken from 
the experiment conducted to demonstrate the main approaches to the translation of online news texts from English into Ukrainian. You can see the headlines in upper case letters and the leads below them:

BRANDON BERNARD EXECUTED IN TRUMP'S FINAL DAYS

Death row inmate Brandon Bernard has been executed in Indiana after last-minute clemency pleas were rejected by the US Supreme Court [29].

СТРАТИ ОСТАННІХ ДНІВ ПРЕЗИДЕНТА ТРАМПА. ПЕРША ВІДБУЛАСЯ, ПРОХАННЯ КАРДАШ'ЯН НЕ ВРЯТУВАЛО

Засудженого на смертну кару Брендона Бернарда стратили в Індіані після того, як Верховний суд США відхилив прохання про помилування [30].

The leads of the source and target texts convey very similar messages, but the headline in Ukrainian is substantially extended. We can see the name of Kim Kardashian, who pleaded the US President not to execute Brandon Bernard, but this fact was presented as her tweet message only in the second part of the source text:

Kim Kardashian West

@KimKardashian

\#BrandonBernard should not be executed:

1. He was 18 at the time.

2. He was not the shooter.

3. The prosecutor and 5 of the jurors now support clemency.

4. He's spent decades in prison w/out a write up, helping at risk youth.

5. There's bipartisan support for his commutation [29, 30].

The target headline prioritises her name, and we see it in the very beginning of the article. At the same time, the Ukrainian translation omits the name of Brandon Bernard in its heading and mentions him only in the lead for the first time, as his name is hardly known to target readers. The transformations of omission and transposition are observed in this translation, whereas the completely opposite approach can be seen in the next example:

BIDEN AND HARRIS NAMED TIME'S PERSON OF THE YEAR

US President-elect Joe Biden and his running mate Kamala Harris have been chosen as Time magazine's Person of the Year in 2020 [31].

ТІМЕ НАЗВАВ БАЙДЕНА І ГАРРІС ЛЮДИНОЮ 2020 РОКУ

Новообраний президент США Джо Байден та його віџепрезидент Камала Гарріс опинилися на обкладинці Тіте. Впливовий часопис називає “Людину року” вже майже сторіччя - від 1927 [32].

The magazine Time is well known for many readers, so it is given the first place in the Ukrainian heading and is not transliterated but written in English. Nevertheless, the Ukrainian lead demonstrates the transformation of logical development, as it can be regarded as more explicative in comparison to the original. It is added that Time is an influential magazine, which has named the Person of the Year since 1927. The translation decisions are mostly situational and can be considered to be optional choices.

\section{Research results: translation challenges in rendering the paratextual elements of news texts}

The experiment conducted at the Translation Department of Taras Shevchenko National University in Kyiv has shown that most students face real problems while translating English paratextual elements because of their special grammar, lexical, stylistic and especially cultural specificity. So let us have a closer look at the most common translation challenges that the students had to solve. The undergraduates enrolled on the course of Translation of Modern Social and Political Texts reached a conclusion that transposing paratextual elements is one of the most frequent translation transformations: 
CROWDED UKRAINIAN HOSPITALS SHORT ON BEDS, OXYGEN, STAFF [33].

КРИТИЧНА НЕСТАЧА ЛІЖОК, КИСНЮ ТА МЕДИКІВ У ПЕРЕПОВНЕНИХ ЛІКАРНЯХ В УКРАЇНІ.

The headline in English is informative and problematic at the same time, but the transposition of theme and rheme in the target text puts more emphasis on the problematic function. The shortage of necessary items in hospitals becomes the theme in the Ukrainian translation.

Nevertheless, this headline was rather transparent in meaning for students and their translations changed little after reading the lead and then the whole article. But some headlines can be quite confusing and the lead becomes the first paratextual element which can help to find a solution:

JOHN STEVENSON: EX-BBC CORRESPONDENT AND PARTNER FOUND DEAD HAD NO INJURIES

A former BBC Wales political correspondent and his partner were found dead in the same room with no injuries, an inquest heard [34].

The lead supplements the headline and answers the questions: who, what happened, where and how:

Heading: КОЛИШНЬОГО РЕПОРТЕРА ВВС ТА ЙОГО ПАРТНЕРА ЗНАЙШЛИ МЕРТВИМИ

Lead: Як повідомляє слідство, валлієць Джон Стівенсон, колишній політичний кореспондент ВВС, та його партнер знайдені мертвими в одній кімнаті, без тілесних ушкоджень.

As the name of the former BBC correspondent is hardly known in Ukraine, it has been moved to the lead in translation. The transfer of the proper name and some extra details to the lead helped the students make the headline concise and sensational in Ukrainian. But this decision was reached only when they were given the headline with the lead. The transposition seems also reasonable when we have complex sentences in headlines:

JOBLESS CLAIMS ROSE LAST WEEK AS CORONAVIRUS SURGE THREATENS TO UNDERMINE RECOVERY

Economists expected 730,000 Americans to apply for jobless aid last week [35].

The economic term "jobless claims" demands some addition in Ukrainian: “заявки на допомогу по безробіттю", as well as the expression "coronavirus surge" - "різке збільшення випадків коронавірусу", which can make the headline too extended in translation. So it is possible to move some information to the lead and resort to generalisation in the headline:

КОРОНАВІРУС ЗАГРОЖУС ЕКОНОМІЦІ АМЕРИКИ

Економісти передбачають, шчо через збільшення випадків коронавірусу 730000 американиів звернуться за допомогою по безробіттю, а отже відновлення економіки США - під загрозою.

Conveying paratextual elements, we should take into account the major differences between morphological and grammatical structures of English and Ukrainian news texts. For instance, future and past events are often denoted with present tense verbs in English headlines:

\section{ELON MUSK BECOMES WORLD'S SECOND RICHEST PERSON}

Tech entrepreneur Elon Musk has topped Microsoft founder Bill Gates to become the world's second richest man after a meteoric rise in his personal fortune [36].

One of the functions of Present Simple tense in headlines in English is to make facts vivid and attention-catching. This function can be performed by nominal sentences in Ukrainian, and the dash is widely used instead of the verb:

ІЛОН МАСК - ДРУГА НАЙБАГАТША ЛЮДИНА У СВІТІ.

However, the usage of past tense is also common in Ukrainian headlines: 


\section{ІЛОН МАСК СТАВ ДРУГОЮ НАЙБАГАТШОЮ ЛЮДИНОЮ У СВІТІ}

Американський бізнесмен Ілон Маск за обсягом статків обігнав засновника корпораиіï Microsoft Білла Гейтса та став другою найбагатшою людиною у світі за версією Bloomberg [37].

We can observe the omission of the final part of the lead: "after a meteoric rise in his personal fortune" in the Ukrainian translation. It is substituted for more precise information "за версією Bloomberg", sо the informative function of the introductory sentence is enhanced in the target lead.

Non-Finite Forms in headlines were pointed out by most of the undergraduate students as a distinctive feature of news in English, which requires appropriate translation transformations in Ukrainian:

\section{CHRISTMAS COVID RULES "NOT AN INSTRUCTION TO MEET UP”}

An agreement to relax Covid rules over Christmas is not "an instruction to meet with other people”, Wales' First Minister Mark Drakeford has said [38].

The dominance of content words and the usage of the infinitive in the heading can cause some misunderstanding for students, while the lead really clarifies the information. At first, the students were given only the headline and they agreed on the following translation:

\section{КАРАНТИННІ ПРАВИЛА ПІДЧАС РІЗДВЯНИХ СВЯТ ЗАБОРОНЯЮТЬ ЗУСТРІЧІ.}

Having been given the lead, which complemented the headline, they decided to rearrange the information in the target text:

КАРАНТИННІ ПРАВИЛА ПІДЧАС РІЗДВЯНИХ СВЯТ

Перший міністр Уельсу Марк Дрейкфорд зазначив, щя хоча вони і домовилися пом'якшити карантинні правила на різдвяні свята, це зовсім не означає, щуо можна влаштовувати зустрічі.

The infinitive of purpose is rendered by a subordinate clause with some implied modality in Ukrainian translation. The subordinate clauses are often used to translate English headlines with non-finite verbs into Ukrainian. The analysis of more than 570 paratextual elements such as headlines, subheadings and leads of online news texts in English proved that most morphological and grammatical features demand transposition in Ukrainian translation, which is often combined with the transformations of omission, addition and substitution. These changes in translation are caused by grammatical discrepancies between English and Ukrainian languages. If students are well-trained in basic translation transformations, have a good command of both languages and take into account the functional integrity of paratextual elements, they are certain to overcome grammatical challenges in translation. Whereas, some lexical and stylistic features of the paratextual elements, namely headlines and leads, demand the extensive knowledge of political, economic and cultural spheres of different countries. For instance, it was timeconsuming for students to translate some headlines highlighting international political relationships. Besides, we can observe some not very accurate translation even in Ukrainian newspapers:

CHINA HOLDS MILITARY DRILL AS US ENVOY VISITS TAIWAN

China says it is conducting military exercises near the Taiwan Strait to "protect its sovereignty" as a top US official visits Taiwan [39].

КИТАЙ ПРОВОДИТЬ ВІЙСЬКОВІ НАВЧАННЯ БІЛЯ ТАЙВАНЮ

Китай проводить військові навчання поблизу Тайванської протоки, щоб “захистити свій суверенітет” [40].

The translation omits the very significant information in the heading - "US envoy" and the synonymic phrase in the lead - "a top US official", so the tension between such countries as the USA, China and its disputable territory of Taiwan is neglected. Moreover, the name and gender of the US envoy caused much confusion in Ukrainian online news 
outlets. Some newspapers even presented the US official as a female representative: "Keith Krach is the highest-level official from the US State Department to visit the island... " [39] “...високопосадовеиь Державного департаменту США Кейт Крач відвідала Тайвань" [41]. Although the news website Укрінформ conveyed correctly the gender of the American politician: "На острів 3 візитом прибу заступник голови Держдепартаменту США Кейт Крач” [40], the very name "Keith" was misunderstood in both Ukrainian versions. These misleading translation decisions can be seen as rush steps and cannot be justified. It is obvious that the female name in English "Kate" is transcoded as "Кейт" in Ukrainian, but not the male name of Scottish origin "Keith", which should be transliterated as "Kiт". The same name of outstanding Keith Jarrett, an American jazz and classical music pianist and composer, is known as Кіт Джарретт in Ukraine. What is more, both Ukrainian news sites have a reference to the original BBC article, which clearly indicates the gender: "Washington said $\underline{M r}$ Krach, who is the US undersecretary of economic affairs" [39]. It is essential to check all translation decisions by reading the whole story and taking into consideration all relevant facts. That is why it is necessary to understand that paratextual elements are always context-dependent, and they should interact with the whole text, even if they constitute a complete summary of the story. It is impossible to win the trust of consumers if the translation is quick enough to be the first on the Internet, albeit of poor quality. True journalists put forth a lot of efforts to gain the audience, and some proper names often become parts of neologisms:

BIDENOMICS: THE GOOD THE BAD AND THE UNKNOWN [42].

The article from the Economist anticipates how Joe Biden's future actions could influence the US economy and creates a new word "Bidenomics" ("Biden" + "economics"). The compound noun is rather transparent and can be quite easily brought into Ukrainian: “БАЙДЕНОМІКА”.

Besides, some neologisms are caused by particular new tendencies or events that take place around the world. Nowadays new-coined words are being created in English headlines due to a Covid-19 pandemic. Most Ukrainian online sources have borrowed the pandemic term "lockdown" and just transliterated it as "локдаун". If it is not possible to copy or calque neologisms in translation, we often have to resort to the transformation of logical development in Ukrainian: "three tier lockdown" - “трирівневий локдаун”, "circuit breaker" - “короткотривалий локдаун", "social bubble" - "соціальна бульбашка", “travel bubble” - “безпековий коридор для подорожей”. That is why it is necessary to analyse the lead which can clarify a neologism or, if it is not enough, even the whole article. The term "travel bubbles" or quarantine-free travel has emerged since the beginning of this year when countries had to seal their borders to foreign visitors:

Heading: CORONAVIRUS: 'TRAVEL BUBBLE' PLAN TO HELP KICK-START FLIGHTS

Lead: Australia and New Zealand are planning a 'travel bubble', or corridor, that will allow the quarantine-free flow of people between the two neighbours [43].

The same article in Ukrainian has been completely rearranged by the BBC translators, as the neologism "travel bubble" had to be introduced into a new culture. The translator of the article decided to start with more general issues and chose for the title a completely neutral heading, while the lead of the English article became the tail in Ukrainian translation:

Heading: ЯК МИ ЛІТАТИМЕМО ПІСЛЯ КОРОНАВІРУСУ

The final sentence of the article: Австралія та Нова Зеландія, наприклад, обговорюють створення так званої “бульбашки” або безпекового коридору, щчо уможливить потоки подорожуючих між сусідніми країнами під час пандемії [44].

The translation decisions signify that the Ukrainian text incorporates some information of the English article, but it is more informative and explicative. 
Modern research also proves high incidence of intertextual inclusions into the paratext, especially into headlines. The experiment conducted among the undergraduates has shown that some precedent names and allusions from literature, especially biblical ones, are the most challenging to recognise and translate:

Heading: BREXIT: WILL BRUSSELS DINNER PROVE TO BE THE LAST SUPPER?

Subheading: Could it be the last supper? [45].

The article does not have a lead paragraph, which is usually graphically distinct from the whole text. Neither the headline nor the subheading provides us with the information which can clarify the implications in them. The allusion to the biblical story of "The Last Supper" creates much ambiguity and is quite challenging to translate. This expression signifying the final meal that Jesus shared with his apostles is commonly known as "Тайна вечеря" in Ukrainian, which is "The Secret Supper" if translated literally into English. That is why a broader contextual analysis is needed to take some translation decisions. The introductory sentence also contains the reference to the Bible:

Boris Johnson will travel to Brussels for the first time in months on Wednesday night to sit and break bread with the EU Commission chief Ursula von der Leyen [45].

The phase "to break bread" in the Bible refers to the Holy Communion or the Eucharist, when Jesus takes bread, breaks it and gives it to others. Today the expression is often used "to affirm trust, confidence, and comfort with an individual or group of people" [46]. At the same time the original article provides some hints on possible private talks during the visit:

If they are willing to make that kind of pact - to say privately to each other, I'm willing to budge if you are too - then that would in theory allow technical talks to get going again [45].

In order to preserve the original Biblical allusion, the following translation decision was reached among the students when they read the whole article:

БРЕКЗИТ: ЧИ НЕ СТАНЕ ТАЙНА ВЕЧЕРЯ В БРЮССЕЛІ ОСТАННЬОЮ?

Then the subheading "Could it be the last supper?" was substituted for the lead paragraph, which was created from the first introductory sentence of the original:

Борис Джонсон поїде до Брюсселю у середу, щзоб поговорити $і$ розділити тайнство вечері з Урсулою фон дер Ляєн, президенткою Європейської комісій.

Та чи не стане ия вечеря останньою?

Subsequently, we can conclude that the usage of cultural units and devices requires the most meticulous approach and cultural adaptation in translation. If allusions in the paratext are recognised and properly defined, it is easier to find a suitable approach to rendering all intended implications in translation. At the same time, we have to pay heed to the most characteristic features of English news writing and adjust paratextual elements to the norms and traditions of the target culture.

\section{Conclusion}

The translation approaches to the paratextual elements of news texts should take into account the following factors:

- translating news texts requires the translator's meticulous approach to paratextual components, together with profound background knowledge and insights into the heart of journalism;

- the translation of paratextual elements presupposes the knowledge of the rules of journalism in source and target cultures, which can be instrumental in rendering appropriate implications of news texts in translation;

- headlines, subheadings and leads constitute a microstructure of news texts and are the most challenging paratextual elements, as they often call for cultural, political and historical competencies of the translator; 
- the translation analysis of paratextual elements of news texts is expected to take into account their intensive textual positions as being interwoven into contextual relationships, which requires the translator's competence and optimal translating decisions;

- headlines and subheadings are regarded to be intensive positions in news texts as they determine the main themes of stories, direct the reader's attention and embody key ideas;

- the translation of headlines and subheadings necessitates the skills in journalism, which can help to create target attention-grabbing equivalents and trigger the reader's expectations;

- headlines as paratextual elements are often characterized by semantic and syntactic complexity and multitargeted functions;

- the translation of news headlines is often context-dependent and involves a careful consideration of their interaction with the lead and the whole text;

- rendering the microstructure of headlines and leads, we often resort to such translation transformations as generalization, omission, addition, substitution, and transposition in translation;

- the analysis of paratextual elements proves that their translation often demands stylistic and cultural adaptation in the target language.

\section{References}

1. A. O'Keeffe, Investigating Media Discourse (New York and London: Routledge, 2006)

2. G. Stanitzek, Texts and Paratexts in Media, Critical Inquiry 32, no. 1, 27-42, (2005)

3. S. Pesce, P. Noto, The Politics of Ephermeral Digital Media: Permanence and Obsolescence in Paratexts (New York and London: Routledge, 2016)

4. T.A. Van Dijk. News as Discourse. (Lawrence Erbaum Associates, Inc., 1988)

5. Translation in Global News ed. by K. Conway and S. Bassnett, Proceedings of the conference, 129 p. (UK: The University of Warwick, 2006)

6. F. Frandsen, News Discourse [microform]: The Paratextual Structure of News Texts (Distributed by ERIC Clearinghouse, 1992)

7. G. Genette, Seuils. Paris: Collection Poétique du Seuil (1987)

8. G. Genette, Paratexts: Thresholds of Interpretation (Cambridge University Press, 1997)

9. R. Skare, Paratext. Knowledge Organization 47, no. 6, 511-519, (2020)

10. J. Y. Frías, Translation Peripheries. Paratextual Elements in Translation, 117-134, (Bern: Peter Lang Series, 2012)

11. V. Pellatt, Text, Extratext, Metatext and Paratext in Translation, 127, (Cambridge Scholars Publishing, 2013)

12. J. Braga Riera, The Role of Epitexts in Drama Translation. JoSTrans 30, 249-268 (2018)

13. K. Batchelor, Translation and Paratexts, (Routledge,Taylor\&Francis Group, 2018)

14. G. Lathey, Children's Literature in Translation Challenges and Strategies, 1-19, (L.N-Y.: Routledge, 2014)

15. M. Carter, Emitexts and Paratexts: Propaganda in EVE Online. Games and Culture 10, no. 4, 311-42, (2015) 
16. D. L. Burk, Emerging Ethical Issues of Life in Virtual Worlds, Charlotte, NC: Information Age Publishing, 33-53, (2010)

17. A. Rockenberger, Examining Paratextual Theory and its Applications in Digital Culture, Hershey, Pa.: IGI Global, 252-286, (2014)

18. J. Gray, Show Sold Separately: Promos, Spoilers, and Other Media Paratexts (New York University Press, 2010)

19. M. Gross, D. Latham, The Peritextual Literacy Framework: Using the function of peritext to support critical thinking. Library and Information Science Research 39, 116123, (2017)

20. I. V. Arnold, Stylistics. The Modern English Language (Moscow, Flinta, 2004)

21. M. D. C. Drout, A Way with Words: Writing, Rhetoric, and the Art of Persuasion (LLC, 2006)

22. V. Zdoroveha, Theory and Methodology of Journalistic Creativity (Lviv, 2008)

23. D. Green, Nine tips on crafting the perfect headline for print and online, Journalism.con.uk, https://www.journalism.co.uk/news/how-to-craft-the-perfectheadline/s2/a744951 (2019)

24. J. Avlon, Our conspiracy theorist-in-chief, CNN, https://edition.cnn.com/2019/08/12/opinions/conspiracy-theorist-in-chief-trumpavlon/index.html (2019)

25. Obituary: Karl Lagerfeld, Chanel's iconic fashion designer, $B B C$, https://www.bbc.com/news/world-europe-47293637 (2019)

26. Карл Лагерфельд: кайзер світу моди і легендарний керівник Chanel, BBC News Україна, https://www.bbc.com/ukrainian/features-47293575 (2019)

27. Why Do We 'Bury the Lede?', Merriam-Webster, https://www.merriamwebster.com/words-at-play/bury-the-lede-versus-lead

28. W. Zinsser, On Writing Well: The Classic Guide to Writing Nonfiction (NY: HarperCollons Publishers Inc, 2019)

29. Brandon Bernard executed in Trump's final days, $B B C$, https://www.bbc.com/news/world-us-canada-55261224 (2020)

30. Страти останніх днів президента Трампа. Перша відбулася, прохання Кардаш'ян не врятувало, ВBC News Україна, https://www.bbc.com/ukrainian/news-55270985 (2020)

31. Biden and Harris named Time's Person of the Year, $B B C$, https://www.bbc.com/news/world-us-canada-55270322 (2020)

32. Тime назвав Байдена і Гарріс людиною 2020 року, ВВC News Украӥна, https://www.bbc.com/ukrainian/news-55270979 (2020)

33. B. Talant, Crowded Ukrainian hospitals short on beds, oxygen, staff, Kyiv Post, https://www.kyivpost.com/ukraine-politics/crowded-ukrainian-hospitals-short-on-bedsoxygen-staff.html (2020)

34. John Stevenson: Ex-BBC correspondent and partner found dead had no injuries, $B B C$, https://www.bbc.com/news/uk-wales-55071426 (2020)

35. M. Henney, Jobless claims rose last week as coronavirus surge threatens to undermine recovery, The Economist, https://www.foxbusiness.com/economy/jobless-claimscoronavirus-pandemic-november-21(2020)

36. Elon Musk becomes world's second richest person, $B B C$, https://www.bbc.com/news/business-55059915 (2020) 
37. Ілон Маск став другою найбагатшою людиною у світі, Суспільне/Новини, https://suspilne.media/82385-ilon-mask-stav-drugou-najbagatsou-ludinou-u-sviti (2020)

38. Christmas Covid rules "not an instruction to meet up", $B B C$, https://www.bbc.com/news/uk-wales-politics-55056743 (2020)

39. China holds military drill as US envoy visits Taiwan, $B B C$, https://www.bbc.com/news/world-asia-54200913 (2020)

40. Китай проводить військові навчання біля Тайваню, Укрінформ, https://www.ukrinform.ua/rubric-world/3102062-kitaj-provodit-vijskovi-navcannabila-tajvanu.html (2020)

41. Китай проводить військові навчання біля Тайваню, Ecnpeco, https://espreso.tv/news/2020/09/18/kytay_provodyt_viyskovi_navchannya_bilya_tayva nyu (2020)

42. Bidenomics: the good the bad and the unknown, The Economist, https://www.economist.com/leaders/2020/10/03/bidenomics-the-good-the-bad-and-theunknown (2020)

43. J. Harper, Coronavirus: 'Travel bubble' plan to help kick-start flights, $B B C$, https://www.bbc.com/news/business-52526272 (2020)

44. Як ми літатимемо після коронавірусу, BBC News Украӥна, https://www.bbc.com/ukrainian/news-52559005 (2020)

45. L. Kuenssberg, Brexit: Will Brussels dinner prove to be the last supper? $B B C$, https://www.bbc.com/news/uk-politics-55240130 (2020)

46. Break bread, Urban dictionary, https://www.urbandictionary.com/define.php?term=Break\%20bread (2010) 